\title{
Interjú Ferenczy Máriával
}

\section{Ferenczy Mária Írta: Kardos Tatjána, Hopp Ferenc Ázsiai Múvészeti Múzeum}

Dr. Ferenczy Mária (1941. október 7. - 2017. december 28.) sinológus, művelődéstörténész 1960-ban érettségizett a budapesti Radnóti Miklós Gimnáziumban. Az országos középiskolai tanulmányi versenyen elért eredményének köszönhetően azonnal felvételt nyert az ELTE történelem tanári szakára, ezzel párhuzamosan kínai szakon is megkezdte tanulmányait. A legendás hírú Ligeti professzor tanítványa volt, innen származott magas színvonalú sinológiai felkészültsége. Diplomáját 1965-ben kínai szakon szerezte meg. 1965 és 1966 között ösztöndíjasként Pekingben tanult, 1966-ban kínai és belső-ázsiai filológiából megvédte doktori disszertációját $A$ középkori észak-kinai nomád államok történetéhez címmel. 1966 és 1970 között könyvtárosként dolgozott az ELTE BTK Kínai és Kelet-ázsiai Tanszékén. 1970-től 1971-ig Szentpétervárott és Moszkvában ösztöndíjas sinológiai kutatóként a Selyemút tangut leleteivel, forrásanyagaival foglalkozott. 1971 és 1985 között az ELTE BTK Kínai Tanszékének kutatója, majd előadója lett. 1980 és 1988 között az MTA Orientalisztikai Munkaközösségének tudományos munkatársa, 1988 és 2003 között pedig a Hopp Ferenc Kelet-ázsiai Mủvészeti Múzeum igazgatója volt. Nyugdíjba vonulása után félállású kutatóként 2007-ig dolgozott a Kelet-ázsiai Múzeumban.

Érdeklődése a kínai kultúra igen sok területére kiterjedt. Kínai írott források, illetve régészeti és művészeti forrásanyag (részben helyszíni tanulmányok) alapján kutatta a Tangut (Xi Xia) Birodalom (Északnyugat-Kína, X-XIII. század) és kultúra emlékeit. Foglalkozott a pénz sajátos megjelenési formáival és szerepével a régi Kínában. (A Magyar Nemzeti Múzeum Éremtára és néhány más, hazai múzeum kínai pénz- és éremgyüjteményét Ferenczy professzor asszony meghatározásaival őrzik.) Foglalkozott a kínai könyvnyomtatás történetével, 2003-ban az Országos Széchényi Könyvtárban rendezett kínai könyvnyomtatás-történeti kiállítást. A múzeumi munka kapcsán kutatásokat végzett a magyarországi keleti mügyüjtés, valamint keleti fotótörténet területén. Kutatásai kiterjedtek a hagyományos kínai világképre és az ezt őrző kínai újévi képekre. A kínai újévi képekkel foglalkozó monográfiáját már nem sikerült befejeznie. 
Ferenczy professzor asszony elhivatott oktató volt, tanítványai alapos filológiai alapozást kaptak, majd korszerü ismereteket és kutatási szempontokat sajátíthattak el. Meghatározó volt szerkesztői tevékenysége is. Kutatási eredményeit tanulmányok, kiállítási katalógusok, könyvek örzik. Férjének, Csongor Barnabásnak mindvégig fontos szakmai segítője volt.

Ferenczy professzor asszony hosszú publikációs listájából itt csak a legfontosabbakat van mód kiemelni. Kínai könyvnyomtatás-történeti témában magyar nyelven az első összefoglalás A Tíz Bambusz Csarnoka. Könyv-és nyomdászattörténeti kiállitás a Kínai Nemzeti Könyvtár kincseiböl címü katalógus (Országos Széchényi Könyvtár, Budapest, 2003). Keleti fotótörténettel foglalkozó müvei közül a legfontosabb a Kincses Károllyal közösen írott Mandarin öszvérháton. Hopp Ferenc fényképei (Magyar Fotográfiai Múzeum - Hopp Ferenc Kelet-ázsiai Művészeti Múzeum, Budapest, 1999). Csongor Barnabással közösen készült $A$ kínai nevek és szavak magyar átírása (Akadémiai Kiadó, Budapest, 1993). A Tangut Birodalommal foglalkozó müvei közül alapvetö a „Dual Economy in the Tangut Empire (on the Basis of the Chinese Sources)" (Études Tibetaines. Actes du XXIX Congrěs international des Orientalistes, Paris, 1976), valamint a „The Formation of Tangut Statehood as seen by Chinese Historiographers" (Tibetan and Buddhist Studies. Commemorating the 200. Anniversary of the Birth of Alexander Csoma de Körös. Vol. I. Akadémiai Kiadó, Budapest, 1984, 241-249). Kínai pénztörténeti tanulmányainak hosszú sorából a legátfogóbb „A pénzforgalom állami szabályozása a középkori Kínában" címü tanulmánya (A Magyar Numizmatikai Társulat Évkönyve 1975-1976, 1981, 33-45). A hagyományos kínai kultúra és az újévi képek témájában igen fontos mü „A modernizáció megjelenése a század eleji kínai ábrázolásokon. Újévi képek Kínából: Jangliucsing” (Ars Decorativa 11 (1991), 119-178). A kínai időszámítás sajátosságait új megközelítésben tárgyalja az „Időszámítás és ünnepkör a hagyományos Kínában” címü tanulmány (Közelitések az időhöz. Néprajzi Múzeum, 2002, 37-51).

\section{Bevezetés írta: Galambos Imre}

Az itt közölt beszélgetés a Távol-Keleti Tanulmányok elöző számában „Interjú Csongor Barnabással" címen megjelent íráshoz kapcsolódik, tulajdonképpen annak második részét alkotja. Eredetileg mindkettőhöz az indítékot az európai 
sinológia történetét dokumentálni hivatott „oral history” projekt adta. A beszélgetéseket három látogatás során folytattuk le, a Ferenczy Máriával készültet 2017. január 19-én. Ez alkalommal azonban a Tanár úr egészségi állapota miatt nem tudott jelen lenni.

Ferenczy tanárnőt elsősorban a Tanár úr kapcsán ismertem, még abból az időből, amikor a Hopp Ferenc Kelet-ázsiai Müvészeti Múzeumot vezette. 2003-ban került sor az Országos Széchényi Könyvtárban a Tíz Bambusz Csarnoka címü könyv- és nyomdászattörténeti kiállításra, ekkoriban a Tanárnő sokat beszélt az előkészületekről, valamint az azokhoz füződő nehézségekről. ${ }^{1}$ A kiállításhoz nyomtatott katalógus is készült, ${ }^{2}$ amely szintén nem volt egyszerü, és - amint az gyakran előfordul - csak a legutolsó pillanatban sikerült leadni az anyagot a nyomdába. De a kiállítás sikeres volt, és a Tanárnő még évekkel később is gyakran emlékezett vissza rá, nem utolsósorban az ezzel kapcsolatos problémákra.

A Tanárnő gyakran beszélt a tangut történelem kutatásáról, mivel már nagyon régről érdekelte ez a terület, és évekkel korábban ő maga is próbálkozott a nyelv megtanulásával. Ez abban az időszakban volt, amikor a Szovjetunióban egy egész csapat kutató múködött tangut témában, felölelve annak nyelvészeti, történelmi, filológiai, illetve könyvészeti aspektusait, és ez természetesen jelentős eredményekhez is vezetett. Leningrádban volt a világ legnagyobb gyüjteménye, és a szovjet kutatók alkották a tudományos munka élvonalát. A Tanárnő is rajtuk keresztül kapta meg egy kéziratnak a másolatát, amelyet aztán megpróbált önállóan feldolgozni. Sajnos az így szinte véletlenszerüen ráosztott anyag kifejezetten nehéz szövegnek bizonyult, ezért nem sikerült megfejtenie. Mint mondta, később Leningrádban más is próbálkozott vele, sikertelenül. Ennek ellenére a tangut nyelv és írás elsajátítása többnyire egy, még meg nem valósított tervként került szóba, többször említette, hogy szeretne újra foglalkozni vele. Még a '70-es, '80-as években írt három cikket a témában, de ezek mind történelmi tárgyúak voltak, és a kínai történetírás szempontjából vizsgálták a Tangut államban végbement eseményeket. ${ }^{3}$ Min-

\footnotetext{
A kiállítás 2003. október 1 és december 23 között történt.

2 Ferenczy Mária, Zhongguo guojia tushuguan, A Tíz Bambusz Csarnoka: Könyv-és nyomdászattörténeti kiállitás a Kinai Nemzeti Könyvtár kincseiböl, Budapest: OSZK, 2003.

3 Mária Ferenczy, "Dual economy in the Tangut empire on the basis of the Chinese sources," in Ariane Macdonald, ed., Études tibétaines: Actes du XXIX. Congrès international des orientalistes, Paris, juillet, 1973, Paris: l'Asiathèque, 1976, 4-7; idem., "The formation of Tangut statehood as seen by Chinese historiographers," in Louis
} 
denestre érdekes volt hallgatni, hogy abban az időben mennyivel nehezebb volt hozzájutni eredeti anyaghoz, illetve hogy mennyire véletlenszerü volt az, hogy melyik szöveget kapta meg valaki. Nyilván egész más világ volt ez, mint ma, amikor a kéziratok és a nyomtatványok nagy része könnyen elérhető jó minőségű reprodukcióként akár digitális, akár nyomtatott formában.

Az utolsó években a Tanárnő egyre többet foglalkozott kínai újévi képekkel (nianhua 年畫), és készült is egy gazdagon illusztrált kötetet kiadni belölük. Ezeket hagyományosan a Holdújévre készítették a jó szerencse reményében, illetve hogy megóvják az otthont az ártó hatásoktól. Általában a piros szín dominált bennük, amely a Kínában a szerencsét jelképezi. Mint a nem elit népi kultúra emlékeit csak viszonylag későn kezdték őket gyüjteni, akkor is föként ott lakó vagy oda látogató külföldiek. A Tanárnő több képet mutatott, és lelkesen azonosította rajtuk a kapuőrző isteneket, valamint néhány, klasszikus regényekből ismert történelmi szereplöt. Többször említette, hogy már szinte teljesen kész a könyv, csak még valamit meg kell rajta csinálnia, illetve alaposan átnéznie. Ezt tekintette legfontosabb munkájának, de számos egyéb folyó tennivaló miatt sosem tudott érdemben hozzálátni a hátramaradt részhez. Ilyen feladatok közé tartozott a már kilencvenes éveiben járó Tanár úr gondozása, illetve az ő munkájában való segédkezés. Az egyik utolsó ilyen projekt a Jinpingmei 金瓶梅 (Szép asszonyok egy gazdag házban) magyar fordításának véglegesítése volt, amelyből elmondásuk szerint már csak a fejezeteket megnyitó versek egy része maradt hátra. Ilyen és hasonló feladatok miatt az újévi képekröl szóló könyvet feltehetően sosem sikerült teljesen befejeznie, és ez csak kéziratos formában maradt hátra.

Ligeti, ed., Tibetan and Buddhist Studies Commemorating the 200th Anniversary of the Birth of Alexander Csoma de Körös, Budapest: Akadémiai Kiadó, 1984, v. 1, 241249; idem., „Tangutok Tunhuangban,” in Ecsedy Ildikó, szerk., Uray Géza Emlékére: Tanulmányok, Budapest: MTA Orientalisztikai Munkaközösség, 1992, 47-57. 


\section{Interjú $^{4}$ \\ 2017. 01. 19. 11:00-13:00 \\ Jelen vannak: Ferenczy Mária, Galambos Imre}

GI: Köszönöm, hogy a Tanárnő az interjú erejéig rendelkezésre állt. Ha mondana egy-két szót - időrendi sorrendben - a családi hátteréről és arról, hogy hogyan jutott erre a pályára.

FM: A családom félértelmiségi család volt, merthogy az édesapám egy körjegyzőnek volt a fia. A körjegyző az a múlt-múlt század végén olyan közigazgatási tisztviselő volt, aki több falunak volt a jegyzője együtt. Tehát nem közjegyző, hanem körjegyző. Nagyapámnak öt fia volt, és mind az ötöt többé-kevésbé taníttatta. Az apámnak a Felsőépítő nevü főiskola jutott, ahol építőmestereket képeztek, tehát olyan szakembert, aki mindenféle építészeti és építési dologhoz tudott annyit, hogy egy nagy ház építését is le tudta vezetni. Ez volt az alapja. Ö aztán építészmérnöki gyakorlatot szerzett, és Müegyetem nélkül eljutott odáig, hogy joggal viselte a tervező építészmérnök címet. Szerette a szakmáját, a munkáját, a hobbija a numizmatika volt. Tekintettel arra, hogy Fejér megyéből jön a család, és az pedig ugye a római időkben Pannónia provincia központja lévén, ott a szántásból római pénz került elő, és a malacok is ilyesmit túrtak elő, már tulajdonképpen a nagyapám kezdte el ezeket gyüjteni. Hát nem került ebből semmilyen világszenzáció, de a gyerekek másként ismerték meg a történelmet, az elődeink életét. Na ennyit az apai családról.

Az édesanyám női szabó volt. Egy sokgyerekes nagyon szegény családnak a leánya, a legkisebbik leány, akinek az lett volna a dolga, hogy ahogy a bátyjai, nénjei egymás után kirepülnek, ő maradjon otthon az öregeket, ebben az esetben a nagyanyámat, gondozni. Mert a nagyapám még az első világháború idején meghalt, úgy, hogy eltünt. Tehát nem volt katona, hanem eltünt valahol a Kárpátokban. Ilyen kis házaló kereskedő volt, így tünt el. Na most nagyanyám rokoni segítséggel (mert ideköltöztek Máramaros megyéből) mindegyik gyereknek adott a kezébe szakmát. Minden tiszteletet megérdemel. Nem ment férjhez újra, viszont minden gyereknek adott szakmát. Anyám volt női szabó, volt szücs, volt kereskedősegéd, még aranymüves is volt köztük.

Az interjú teljes egészében szöveghủen lejegyezve jelenik meg. 
Ez egy ilyen különös házaspár volt abban az értelemben, hogy elég messziről kerültek össze. De szerették egymást, és amennyire én vissza tudok emlékezni, jól megvoltak. Az volt a közös ambíciójuk egyetlen gyermekükkel kapcsolatban (mert nekem testvérem nem született már, én ugye a háború előtt, a háború kezdetén láttam meg a napvilágon, '41-ben születtem itt Pesten), hogy tanuljak. A szellem kimúvelése mindennél fontosabb, és legyen minél teljesebb, sokoldalúbb. Ennek megfelelően jártam ide a szomszéd házba általános iskolába, mert itt volt egy nagy hagyományú iskola. A Radnóti Miklós gimnáziumban, a XIV. kerületben érettségiztem, humánosztályban, mert akkor még így osztották fel az osztályokat. Ez azt is jelenti, hogy én ott tanultam valamennyi latint - nem olyan sokat, mint mondjuk a férjem egy emberöltővel korábban. Ezzel mentem egyetemre.

Na most a Kínai Tanszékre úgy kerültem, hogy nem volt családi indíttatás vagy valamilyen extra háttér ebben a tekintetben, hanem azt kell, hogy mondjam, hogy jókor voltam jó helyen. Merthogy a Radnótiban magyar szakkörbe jártam egy csodálatos tanárnőhöz, aki nem volt más, mint Barnabás első felesége, Faludi Ágota. ${ }^{5}$ Ö szólt egyszer, hogy a férjéék az egyetemen a Kínai Tanszéken középiskolások számára szerveznek szakkört, és ha érdekel, menjek el, nézzem meg, hogy milyen. Akkor már tudott volt rólam, hogy én minden tücsköt-bogarat elolvasok, és nagyon sok minden érdekel. Köszöntem szépen, elmentem, és azóta ott ragadtam. Ugye hát másfél évig a szakkörön, mert harmadikas voltam, amikor ez történt, aztán felvételiztem. A felvételin nem álltam volna meg a helyemet a bizonyítványaim ellenére, mert nagyon gátlásos kislány voltam, és a szóbeli vizsgák nekem rémálom és még annál is rosszabb dolog volt. Írásbeli vizsgáim mindig jók voltak, de szóbelizni nem tudtam. És ebben az esetben az volt a szerencsém, hogy az országos középiskolai tanulmányi versenyen történelemböl voltam országos második, és ez akkor azt jelentette, hogy felvételi nélkül a Bölcsészkarra oda vesznek fel, ahova mondom. Illetve most már tantárgy szerint irányítják a népeket, de ez akkor még így ment.

Na most így mondtam a kínait, tekintettel a szakkörre, mint elözményre. Barnabás adott nekem egy hosszú, szép irodalomjegyzéket. Ez is a mostanihoz képest nem volt olyan hosszú, de azért volt rajta mit olvasni meg rágni. Azt a felvételire elolvastam. Nyelvet nem kellett tudni, mármint a

5 Faludi Ágota (1925-1963), finnugor nyelvész, az osztják és chanti nyelvről jelentek meg tanulmányai. 
kínait, úgyhogy azzal csak az egyetemen találkoztam. Az volt viszont felvétel, hogy két európai nyelven az ember tudjon jól olvasni és használni a kínai idegen nyelvü szótárakat és így tovább.

GI: És melyik volt a Tanárnőnek ez a két európai nyelv?

FM: Orosz és német. Merthogy akkoriban, amikor én elkezdtem, az orosz még kötelező volt. Aztán rá kellett jönnöm, hogy a sinológiában hasznát fogom venni, tehát '56-ban, amikor el lehetett vetni magunktól ezt a kötelező nyavalyát, akkor én nem vetettem el, hanem legalább szinten tartás erejéig tanultam tovább. Le is érettségiztem belöle. A másik nyelve az osztályomnak a német volt. A harmadik nyelv, amiből érettségiztem, az volt a latin. Máig nem győzöm sajnálni, hogy akkoriban angolt tanulni csak külön pénzért tudtam volna, és az azért a szüleim minden igyekezete ellenére nem nagyon került. Úgyhogy angolt akkor nem kezdtem tanulni. Később aztán tanultam, de máig nem vagyok benne valami fényes, különösen tekintettel arra, hogy annak idején ösztöndíjak sem nagyon voltak. Én meg nem voltam kalandozós természet, ami akkor kellett volna ahhoz, hogy angol nyelvterületre eljussak. Aztán mikor már lehetett volna, vagy csak pénzkérdés volt, addigra meg már megöregedtem. Úgyhogy nem voltam angol nyelvterületen. Zárójel bezárva.

De hát az orosszal, némettel azért ott el lehetett boldogulni, annál is inkább, mert az első két évben a Haenischnek ${ }^{6}$ a klasszikus nyelvkönyvéből tanultuk még a klasszikus kínait, és nem túlságosan sok anyagunk volt még angolul, egy-két kitünő szakirodalmat kivéve, ami mégiscsak megvolt. Akkor elkezdtem a történelem és a magyar szakot is, mert az akkor felvétel volt. Az az apróság történt, hogy én felvételi nélkül kerültem be, ha akkor én azt mondtam, hogy kínai szak, akkor én kínai szakos lehettem. Hacsak valami főbenjáró szamárságot nem mondtam, és azért nem próbáltak meg kiakolbólítani a felvételiztetők. De úgy tűnik, hogy ilyen nem volt. Viszont volt két hely, és volt velem együtt három posszibilis jelölt. Azt megtették Barnabásék, és azt én sosem értettem meg később, mert egy tizennyolc éves gyereket, aki lelkiismeretes ember, de teljesen járatlan a világ dolgaiban, nem lehet ilyen helyzet elé állítani, hogy azt

6 Erich Haenisch (1880-1966), német nyelvész professzor, aki elsősorban mongol és mandzsu nyelvvel foglalkozott, de a sinológia terén is születtek nagy hatású munkái. Ezek közül Magyarországon a Lehrgang der klassischen chinesischen Schriftsprache Studienausgabe (Leipzig: Asia major, 1929-1933) címü klasszikus kínai nyelvkönyv volt használatban. 
mondták, hogy én úgyis ott vagyok a tanulmányi verseny miatt, hát járjak be a kínai szak óráira, félévkor átvesznek. Hát persze, hát ha két tehetséges, lehet hogy nálam tehetségesebb jelöltnek az indulása múlik ezen, akkor ez a legkevesebb, amit az ember megtehet. Mert a munkabírásomban bíztam.

Csak azt nem mondták meg Barnabásék, és lehet, hogy Barnabás, aki valami abszolút gyakorlatiatlan ember, nem is tudta, hogy akkor vesznek át, hogyha a leadandó szakon nincs négyesnél rosszabb vizsgajegyem. Úgyhogy aztán hajtottam, mint a güzü, és megcsináltam. De ez ilyen módon elég nehezen kezdődött. Az már sokkal-sokkal később volt, amikor különböző turbulenciák miatt nem egyszer előfordult, hogy csak azzal tudtam magam vigasztalni, illetve megfelelő lelki kondícióban tartani, hogy gondoljam meg, hogy ami nekem nagyon rosszul kezdődik, az jól fog folytatódni. És ezt akkor még nem tudtam. De azért sikerült megcsinálni. Na így volt, így lettem kínai szakos. Ez 1960-ban volt.

Akkor más volt még a kínai szak még ahhoz képest is, ahogy ezt maguk látták, mert akkor még ez úgy ment, hogy a szak ambíciója a tudományos utánpótlás képzése, nevelése volt, ami azt jelentette, hogy kellett kétévenként egy ember. Plusz arra kellett ember, és az lett a kevésbé tudományra való, de egyébként jó fejü és szorgalmas diákból, hogy legyen, aki majd a nyelvtanárokat tanítja. Tehát nem nyelvet tanítson, hanem majd a nyelvtanárokat tanítsa. Hát ugye mi hárman voltunk ebben az extra helyzetben, hárman kezdtük el. $\mathrm{Na}$, első szigorlatra, vagyis második félév végére egyedül voltam, és attól kezdve egyedül végeztem a szakot, mert sem elöttem, sem utánam való évfolyam nem volt.

GI: És egy személynek tartották az órákat?

FM: Igen. Ez tulajdonképpen már ilyen mentoralapon, ami hát egy óriási nagy dolog volt. Igyekeztem ki is használni, már amennyire egy diák ennek tudatában van, hogy milyen nagy ajándékot kapott. Mert ugyanakkor ez elég nehéz is, mert nincs semmilyen összehasonlítási lehetőség, hogy na, én ennyit dolgoztam, én ezt tudom. A másik többet, kevesebbet, és a fene egye meg, kétszer annyit tud, vagy ihaj, feleannyit csak. Tehát egyszerüen nem voltak összehasonlítási lehetőségek, és én úgy éreztem, hogy ez nehezíti az én dolgomat. De egyszerüen ez volt. És el is végeztem ötödév végére a szakot. Akkor még a szakdolgozatírásra nem voltak külön évek rendszeresítve, vagy évek lehetősége nem állt fent. 
A következő ilyen sajátos mozzanat az volt, hogy akkoriban Ligeti Lajos professzor $^{7}$ volt még mind a két tanszéknek a vezetője, tehát a BelsőÁzsiának is meg a Kelet-Ázsiának vagy Kínai Tanszéknek is. Ezt az öreg társadalmi munkában vállalta el, olyan értelemben, hogy ő nem kapott azért külön pénzt, hogy két tanszékkel dolgozik és vesződik. Ö adott bizonyos kínai órákat (nyelvtörténetet, ezt-azt, nem tudom már), de egyébként az volt a szokás nála, hogy az összes diákjának ott kellett ülni az ő összes óráján. Ö nem foglalkozott azzal, hogy aztán kinek milyen egyéb órái vannak még, mit csinál, mit nem csinál, azt intézzék el a tanársegédjei, meg mit tudom én. Viszont minden óráján ott kellett ülni. És volt egy óra, ami valóban közös volt mindenki számára: a szeminárium. Az egyéb órákról annyit, hogy arra emlékszem, példának okáért, hogy mikor én elsőéves voltam, akkor ott kellett ülnöm a nyelvtörténet óráján is. Büdös kukkot nem értettem belőle, már bocsánat a kifejezésért. De az biztos, hogy később egy csomó dologban segített nekem az, hogy ez átment a fejemen. Mert figyelni kellett. Úgyhogy ennek is megvolt a maga haszna, legfeljebb a mai fiatalságnak az időbeosztását ez nagyon feszegetné, mert nem lehetett ötvenháromféle helyen dolgozni közben, meg nem tudom micsoda. Ha az ember diák, akkor tanuljon. Pont.

A szeminárium az egy nagyszerú óra volt, mert az úgy nézett ki, hogy ott volt elsőéves kínai szakostól a mondjuk negyedéves tibeti szakosig és ötödéves mongol szakosig mindenki. Mindenki kapott a félév elején egy dolgozattémát. Be volt osztva, hogy kinek mikorra kell megírnia, és hogy ki fogja bírálni. Egyébként aztán mindenkinek el kellett olvasnia a dolgozatot, és mindenkinek hozzá is kellett tennie a maga kis nyúlfarkát, ha tudta, ha nem. Ez is óriási jó dolog volt, mert egyrészt egy csomó szakma különböző friss problémáival kerültünk kapcsolatba, és ha más nem, akkor valami kis módszertani hozadéka a dolognak volt. Másrészt pedig aki ezen a húsdarálón végigment, az megtanult nyomdakész kéziratot előállítani, és az nagyon nagy nyereség volt. Azt nagyon kevés helyen tanították akkor az ELTE-n. Ezt sem tudom, hogy most hogy van, valószínúleg most sem jobb a helyzet ebben a tekintetben. Annál is kevésbé, mert

Ligeti Lajos (1902-1987), orientalista nyelvész, egyetemi tanár, a mongol és török nyelvek világhírü szakértője. Amint az interjúból is kitünik, jelentős szerepe volt a magyar Kelet-kutatás megteremtésében. Lásd „Interjú Csongor Barnabással”, TávolKeleti Tanulmányok 10:1 (2018), 1-31. 
hiszen most egészen mások és szétszórtak a népek. De ez egy nagyszerü iskola volt. Nagyon jó.

Na most általában a témák azok megintcsak évfolyamtól és delikvenstől függően különböző jellegűek és színvonalúak voltak. Első-, másodévben egy-egy recenziót kellett írni valamilyen nyomtatásban megjelent cikkből. És hangsúlyozom, hogy recenziót, nem ismertetést, mert a kettő között az a különbség - tanította nekünk Ligeti -, hogy az ismertetésben előtálalom, hogy mi van az illető müben, cikkben vagy könyvben, ha viszont recenzens vagyok, akkor megpróbálok valami picit hozzátenni vagy rosszabb esetben elvenni belöle. Ez is feltétel volt, hát aztán hol sikerült, hol nem.

Na most nekem az első-legelső szemináriumi dolgozatom Ligetinél, az obligát ismertetés, akarom mondani, recenzió nem volt más, mint a Jevgenyij Ivanovics Kücsánovnak az „Ocserk isztoriji tangutszkovo goszudarsztva" (A tangut állam történelmének vázlata), ${ }^{8}$ még folyóiratcikk formában. Ott tulajdonképpen az állam berendezkedéséről akart szó lenni, nem a hosszú történeti, mindenféle köztörténeti dolgokról és a kultúra ágairól-bogairól. Az, hogy az állam berendezkedéséről volt szó (millió kínai írásjegy, és ami jár vele) azt jelentette, hogy én elkaptam és elkezdtem a dolgot marcangolni. És akkor azért kiderült az számomra, hogy még azért nem elég elmélyült a dolog kínai elemeinek és a valóban tangut, tehát másfajta törzsi elemeinek vagy törzsi eredeti elemeinek a megkülönböztetése. Hát gondolom aztán mire a könyvet megírta Zsenya Ivanovics, akkor már nyilván másként volt ő is ezzel a dologgal. Mindenesetre én akkor igyekeztem apait-anyait beletenni és ezt megfogalmazni úgy, ahogy nekem sikerült.

Hát aztán szétszedték rendesen, ahogy ezt ilyenkor kell, kő kövön nem maradt, az utolsó elképzelésig mindent. Az volt a végén a gombostüzés. Gombostükkel is megszurkálták rendesen. De aztán nem nekem, de a fülem hallatára azt mondta az öreg a tanársegédjének, hogy „Oroszlánkörmök, fiam!” Ennyiben maradtunk. Na így kezdődött a tangut téma. Na most bevallottam, hogy milyen régen, és ahhoz képest én nem sokat publikáltam ebből. Pedig az egyetemi szakdolgozatom és az egyetemi

Jevgenyij I. Kücsanov (1932-2013), orosz orientalista kutató, a tangut történelem és irodalom egyik legnagyobb müvelője és fordítója. A szóban forgó mü 1968-ban jelent meg először. 
doktori disszertációm is ez volt. Ma már nem bánom, hogy nem jelent meg, mert a címétől kiütést kapnék.

GI: Miért, mi volt a címe?

FM: „Az északnyugat-kínai nomád államok történetéhez”. Na most a nomád meg az állam a mostani fejemben nem fér össze. De akkoriban nem ez volt az érdekes számomra. Abból a szempontból viszont sajnálom, hogy végül is elejtődött a dolog, és nem lett belöle komolyabb dolog, hogy elővettem a történetírók tangut fejezetét (a Songshi 宋史 és Liaoshi 遼史 ${ }^{9}$ megfelelö fejezetét), és ott időben páhuzamosan fut az, ami a Songshi-ben le van írva meg ami a Liaoshi-ben le van írva. Elkezdtem ezt a kettőt összenézni, és szépen sikerült kielemezni a történetíró módszereit. Ez egy köztudott dolog egyébként, de nem szokás azzal foglalkozni, pedig tanulságos volt az is, hogy tulajdonképpen az az alapvető eljárás, hogy amit fontosnak tart, azt kimásolja. A következő fontosat utána másolja, aztán megint. Oldalak voltak úgy, hogy össze lehetett rakni az igazi eseménytörténetet: ez a Songshi-ben, a következő a Liaoshi-ben, aztán ami a Songshi-ben utána jött, az ezután következik, és így tovább.

GI: Ezek a shilu-k 實錄, ugye?

FM: Hát ugye amikor a császár elfogadta a történetírókat, akkor a shilu-kat elégették. Tehát tulajdonképpen azokhoz lehetett közelebb jutni. De azokról azt tudni, és hát ezek a mandzsu korból vagy a későbbi időszakokból maradtak fent, talán már a Ming-korból is, tehát ott tudni lehetett, hogy mi a módszer. De azért amikor már így több fázison megy át, akkor az már nehezebb. De még itt is voltak olyan részek, amiket szét lehetett, ki lehetett szedni. És azt hiszem, hogy egy-egy ilyen elemzés az bevilágító, akkor is, ha ez apróság. Ez megmutatta azt is, hogy mennyire kínai az, amit leírnak a kínai történetírók kínai szemlélettel. De hát ők kínaiak, szóval az rendben van. Csakhogy ebböl levonni bizonyos következtetéseket az már nehezebb. Hát ilyesmik voltak, de hát ez aztán elmaradt. Ezt a disszertációt akkor tudtam megvédeni, amikor az első kínai esztendő után, az első és egyetlen kínai esztendő után, ami nekem adatott, hazajöttem. Merthogy elmentem még tintás diplomával egy évre Kínába. Akkor úgy

9 A Songshi és a Liaoshi a Song, illetve Liao (Kitaj) dinasztia hivatalos története, amelyet a mongol korszakban állítottak össze. Mindkét mü Toqto'a (1314-1356) történész irányítása alatt készült el az 1340-es években. 
volt, hogy egy évre a Yuyan xueyuanbe kerülök, ${ }^{10}$ kerültünk is többen, és aztán egy másik év lesz, amikor ki-ki a szakmáját tanulhatja.

GI: Odakint mit tanultak a Tanárnőék?

FM: Nyelvet, kérem, nyelvet.

GI: Tehát csak nyelvet. És irodalmat, ilyesmiket? Klasszikus kínait?

FM: Némi klasszikus volt, de nem sok. És hát nagyon kemény dolog volt, mert ez volt '65-66, tehát belementünk a kulturális forradalom első idejébe, tulajdonképpen még ott azt átéltük.

GI: És az milyen volt?

FM: Mindjárt mondom. Az első, ami fontos, az az, hogy nagyon elzártan éltünk. Az iskola nem kelet-európai típusú kampusz, ahol minden van, és ennek megfelelően nem kell kimenni. Ez a Yuyuan xueyuan akkor szemben volt a Waiyu xueyuannal, az Idegen Nyelvü Főiskolával, ahol voltak diákok, volt egy osztály, akik magyar szakosok voltak. Velük nem volt szabad találkozni, például. És így tovább. Amikor már rájöttem, hogy nem a saját gátlásaimnak és ügyetlenségemnek köszönhetem, hogy senkivel nincs kapcsolatom, hanem teljesen elzártan élünk, akkor gondoltam egy merészet, és azt kértem az igazgatóságtól, hogy adjanak nekem kínai tanulópárt. Netán lakótársat. Hát itt a Ménesi úton [az Eötvös Collegiumban] a kínai diákok, akik voltak, azok magyarokkal laktak együtt. Ez a természetes közege a nyelvtanulásnak, hát jó vicc. És aztán meg is csinálták, két nagyon derék lánnyal költöztettek össze. Nem eggyel, kettővel. Angol szakosok voltak.

Heti 20-24 nyelvóránk volt, ezen felül konzultáció, ami személyre szabott hibajavítás volt. És hetenként kétszer filmvetítés, ahol persze nem volt más hang, mint a kínai, tehát a mellettünk ülő tanárt szabad volt kérdezni, de egyébként arra ment ki a játék, hogy minél elöbb értsük meg jobban. Voltak programok, kirándulások, szóval nagyon tisztességesen csinálták, azt az egyet leszámítva, hogy nem voltunk szabadon engedve. Én azt nem tudom megmondani (és máig nem tudom, de most már mindegy is), hogy ebből volt-e olyan tényező, ami minket védett, tehát hogy milyen feszültségek voltak az akkori kínai társadalomban. De tény az, hogy ez így azért elég kemény volt. És hát külön menzán étkeztünk, nem a kínaiakkal együtt,

10 Yuyan xueyuan 語言學院 (Nyelvi Főiskola), a mai Pekingi Nyelvi és Kulturális Egyetem (Beijing Yuyan Daxue 北京語言大學) elődje. A Kínai Népköztársaságban tanuló külföldi diákok egy jelentős része itt végezte el a nyelvi alapképzést. 
nyilvánvaló módon. Így is lefogytam, soha életemben olyan sovány nem voltam, mint akkor. De az nem baj, mert az egészségemnek nem ártott meg. Aztán még országjárás is volt, szóval voltunk vidéken - vidéken, hát a történelmi fővárosokban, vidéken, ugyebár. Úgyhogy nagyon jó volt sok szempontból. De mondjuk irodalomórák már nem voltak, és hát a tanítás módszerei is nagyon iskolások voltak. Hatékonyak, az kétségtelen. De hogy felnőtt fejjel ott üljön az ember, és ezt úgy csinálja, az elég nehéz volt. Mit mondjak még?

GI: Hát hogy a kulturális forradalomból mit éreztek, hogyan érte el a szele a Tanárnőéket.

FM: Ja igen. Hát először úgy nézett ki, hogy a szél kívül marad a kampuszon, mert hiszen ők nem jöttek be, mi meg nem mentünk ki. De megjelentek a tacepaók, örületes faliújságok. Már őrületes most csak az, hogy amilyen nagyok voltak, és hosszúak, és az ember ott silabizálta egy darabig, aztán képtelen volt végignézni. Akkor elkezdtek - az iskolának egy olyan részén, ahova mi, külföldi diákok nem láttunk oda, tehát csak a hangok jöttek mindenféle nagygyüléseket tartani, amiből az ember rendszerint nem sokat értett. Hangzavar is volt, meg a kórusban kántálást meg egyebeket sem. De azért valamennyit felfogtunk abból, hogy itt most valakit lelepleznek, vagy nem tudom, micsoda. Aztán akkor elkezdtek kicserélődni a tanárok.

Még mindig tartották azt, hogy az iskola rendje a szokásos rend, időnként ugye kisvizsgákkal, zárthelyi dolgozatokkal, amivel azt kell, és időnkénti kulturális programokkal. De látszott, hogy egyre feszültebb a dolog, például odáig menőleg, hogy nem csinálunk-e valami olyasmit, ami nem a kedvükre való, vagy nem az ő szájízük szerint való. Lapot terjeszteni, vagy nem tudom mi. Mert én egy ilyen nem túl nagy zárt táskával járkáltam, és elkezdett probléma lenni az egy-egy kis kiránduláson, hogy a táskát mindenhol cipelem magammal. Aztán mutattam, hogy mi van benne: zsebkendő meg ilyen higiéniai felszerelés, ami lányoknak néha kell. Ezzel együtt az egyik utolsó alkalommal már csak úgy tudtam bemenni a mosdóba a mit tudom én melyik parkban, hogy kivettem belöle a pár zsebkendőt, és a táskát a kezébe nyomtam a tanárnak. Ez egy nagy semminek tünik, de hogy milyen feszültség az, hogy a szemérmetes és nagyon rendes, tisztességes tanárok ezt így éljék meg.

Ami a politikai részét illeti, minket kihagytak nagyjából, tehát nem voltak különböző fejtágítások meg leleplező magyarázatok. Hálás is vagyok érte, mert legalább tanulni lehetett. De hát szóval, hogy mondjam, ez vett 
minket körül, az utcáról, a rádióból, a hangosbeszélőböl ennek a hangulata, hangja folyt tulajdonképpen. Én nem tudom elmondani most ennek az időrendjét, hogy mikor kezdődött ez, és mikor folytatódott az, és mikor volt, amikor ez az utolsó kirándulás történt. De az is tény, hogy még elutaztunk Dél-Kínába júliusban, amikor már elég sok minden történt.

GI: Ez'67-ben volt?

FM: Nem, '66-ban,'66 nyarán. '67-ben már azt hiszem, nem lehetett volna, de akkor már ott sem voltak a külföldi ösztöndíjasok. Na most ebbe is bele kell számítani azt (és ezt mondjuk talán nem szánom a nemzetközi nyilvánosság egy részének), hogy akikkel együtt utaztunk például délre, azok diáktársaink voltak természetesen, de volt egy csomó nyugati, sőt talán még egy árva amerikai srác is, akik jó sok pénzt fizettek azért, hogy ez megtörténjék. Mármint az utazás. Nem tudom, hogy ha ez nincs, akkor minket ugyan elvisznek-e olyan messzire. Hát erről én csak ilyeneket tudok mondani.

GI: És amikor visszajöttek a Tanárnőék?

FM: Amikor visszajöttünk? Na most, ha nem kell visszajönni, mert nem ilyenek az állapotok, akkor lett volna még egy év a Beida valamelyik történeti tanszékén. Erre sem került sor később sem.

Amikor hazajöttünk, akkor utána én a tanszék könyvtárosaként kezdtem dolgozni, noha könyvtárosi képzettségem nem volt. Viszont ez alatt az időszak alatt, amíg könyvtáros voltam, csináltam meg a szakdolgozatból a disszertációt, és megvédtem. Ott még azt az egyet érdemes mondani, hogy a felsőbb évfolyamokon tanultam valamennyi tibetit is, belső-ázsiai filológia volt a melléktárgyam a doktorátusnál. Akkor 1970 őszéig voltam könyvtárosa a tanszéknek, és akkor elmentem egyéves ösztöndíjjal a Szovjetunióba (mert oroszul tudtam, annyira amennyire). Moszkvában beosztottak az egyetemen a Kínai Történelem Tanszékre, ahol volt egy csomó nagyon rendes hölgy meg egy hárpia tanszékvezető, Isten nyugosztalja. Hát vele nem tudtam zöld ágra vergődni, de a kolleganők segítettek mindenben, hogy kiigazodjam, hogy könyvtári olvasójegyem legyen, hogy ez legyen, hogy az legyen, minden.

És akkor végeredményben ott nekiálltam olvasni. Néhány hónapig tulajdonképpen mást sem csináltam, és aztán viszont átmehettem Leningrádba. Én ott is az egyetemtől függtem, mert ez az ösztöndíj az olyan volt, viszont ez nem zavarta az intézetbeli kollegákat, hogy felkaroljanak. Akkor még 
Kücsanov is aránylag kutató volt, de hát ott volt a Kszenyija Boriszovna, ${ }^{11}$ akkor élt még a Terentyjev-Katanszkij ${ }^{12}$ is, és aztán hát ott voltak a sinológusok: a Lev Nyikolajevics, ${ }^{13}$ a Dunhuang-szakértő és még többen mások is. Na, ott aztán igen jól éreztem magam, és hát ott a könyvtár is olyan más, és ott voltak a kéziratok. Én akkor láttam ott először ilyen kéziratot, de a Lev Nyikolajevics megtanított arra, hogy hogy lehetett a papírokat értékelni vagy felismerni, hogy mi milyen. Aztán a Kszenyija az ő nyelvtani, nyelvészeti tudásából mutatott egyet-mást, ez tőlem távolabb állt, de abban a modern formában, ahogy ő müvelte a nyelvészetet, úgy már érdekelt is tulajdonképpen. De hát megmaradtam a magam müvelödéstörténeti profiljánál egyébként. És akkor ott megmutatták a különböző jellegü illusztrációkat a különböző kéziratokhoz. Az valami egészen óriási volt ott, és nagyonnagyon sokat tanultam tölük, ami azt illeti.

És az egyetemen sem volt rossz, mert az egyetemi fónököm (most szégyen, hogy nem tudom a nevét megmondani, mert jó érzéssel gondolok rá vissza) is rendes volt, és ő nem kívánt tőlem semmi, a többi dologhoz nem illő házi feladatot, csak azt, hogy amennyi csak belefér, csináljam meg, és írjak egy-két oldalas beszámolót arról, hogy mit csináltam. Hát ennél könnyebb feltételeket nem lehetett volna szabni. Nagyon jó volt. Amikor visszajöttem, akkor már nem könyvtárosnak jöttem vissza, hanem beosztott kutatónak, de egyetemi státusban. Ez egy elég furcsa állapot egyébként, mert nagyon kényelmes abból a szempontból, hogy kevesebb órát kell tartani, mint egy egyetemi tanársegédnek, de ugyanakkor mindazokban az aprócska elönyökben, ami egy egyetemi tanársegédnek van, abban az emberek nem volt része. Tehát például a fizetése is stagnált három éven keresztül, a szabadsága kevesebb volt, a nyarat nem vehette úgy ki stb. Mindegy, boldog voltam tőle, hogy ott vagyok. Lassan az is kialakult, hogy tanítottam is. Annak is nagyon tudtam örülni, mert szerettem csinálni.

11 Kszenyija Boriszovna Kepping (1937-2002), orosz nyelvész, a tangut nyelv egyik legjelentősebb kutatója. Legnagyobb hatású műve a tangut nyelv morfológiájáról szól, de számos fontos fordítást is kiadott, többek között Sunzi $A$ hadviselés müvészete című kínai munka tangut változatáét is.

12 Anatolij Pavlovics Terentyjev-Katanszkij (1934-1998), orosz kutató, aki elsősorban a tangutok anyagi kultúrájával és könyvészetével kapcsolatban publikált.

13 Lev Nyikolejevics Menysikov (1926-2005), orosz sinológus, a dunhuangi kínai kéziratok katalógusának fő szerzője. Mint a kínai kéziratok és nyomtatott könyvek legrangosabb szakembere, ő készítette el a Khara-khotóban talált tangut anyag kínai részének a katalógusát is. 
GI: És mit tanított a Tanárnő akkoriban?

FM: Klasszikus kínai nyelvet kezdőknek. Különböző müvelődéstörténeti kurzusokat találtam ki, és ókori, középkori történelmet (ha akarom így megnevezni ezeket) tanítottam. Hát még én is a Haenischt használtam, mert nem volt más. Ugyanakkor viszont én (már nem diákkoromban, amikor kínlódtam a német magyarázatokkal) akkor már tudtam értékelni azt az előnyét, ami az, hogy ezt ugye sokféle szövegből válogatta össze az öreg Haenisch, de a tankönyvnek az is az egyik hibája, hogy nem elég redundáns a szöveg, ha már egyszer tankönyv.

Csináltam olyan müvelödéstörténeti kurzust is, ami bizonyos szövegeket ebből vett ki, és akkor azokat elemeztük, hogy végül is most milyen világképet tükröznek, és hogy akkor az hogy épülhetett fel azoknak a fejében, akik ezeket leírták, és akik ebből tanultak száz évvel korábban. Én úgy emlékszem, hogy a diákok szerették, vagy legalábbis nem utálták nagyon ezt a kurzust. Történelemből kellett bevezető kurzust tartani, tehát az ókortól az ópiumháborúig. Ezeket nem szerettem olyan nagyon, hanem ennél kisebb merítést, és akkor azt körüljárni és úgy körüljárni, hogy egy kicsit jó, ha van politikatörténete, ha van társadalomtörténete, és hogy vajon hogy éltek ezek az emberek. Lényegében olyan gazdag tárgykultúra maradt ránk, hogy ha valaki nem veszi észre, hogy ezzel mit lehet kezdeni, ha módja van rá, akkor az nem tanár szerintem.

Újra Kínába '85-ben és '87-ben jutottam el. '85-ben az egy-két hónapos ösztöndíjféle volt, akadémiai cserébe, akkor, amikor az Akadémia megkötötte a csereegyezményt a Kínai Társadalomtudományi Akadémiával. Akkor még nem tudták, sokan különben sem tudják az akadémiai népek között, hogy Kínában vendégnek lenni milyen jó. Tehát nem nagyon tülekedtek ezért az utazásért, akkor úgy meg tudtam kapni két hónapot. El is mentem, én voltam akkor az első ilyen delikvens. Egy csomó mindenben mi sem ismertük az ottani viszonyokat, és hát ők sem ismerték azt, hogy ha elolvassák az én papíromat, hogy hát akkor a mögött mi van. Ennek megfelelően azt hiszem, hogy legalább egy ranggal magasabban fogadtak, mint ahogy én voltam.

Én mindenesetre nagyon jól éreztem magam, és nagyon hálás vagyok máig, hogy egyrészt teljesítették minden kívánságomat, amiket könyveket, kéziratokat meg akartam nézni, azt mind megmutatták, másrészt pedig csináltak nekem egy nagy körutazást, amit ha össze kell foglalni, azt tudom mondani, hogy egyszerüen új képem lett a kínai müvelödéstör- 
ténetröl, ami elég fontos dolog volt. '87-ben a másik alkalommal csak három hétig voltam kint, de Dunhuangban voltam. Ez tangut ügyekben is elég fontos tud lenni, de egyébként is mindenféle müvészettörténeti és művelödéstörténeti szempontból is. Engem változatlanul nem a művészettörténeti része érdekelt, azon kívül, hogy gyönyörủ szép. De hát még ezt is el kellett hozzá mondanom.

Tehát az egyetemen voltam beosztott kutató. Akkor ott még csinálgattam a tangut ügyekben is ezt-azt, de aztán ez valahogy egy kicsit befulladt, mert nem kaptam támogatást, se érdeklődést, se semmit. Viszont feladattal meg annyival elláttak, részint az egyetemen, részint a Tőkei Ferenc kutatócsoportjában, ahova aztán átkerültem, hogy tulajdonképpen nem volt mit sírnom azért, hogy a tangutot nem nagyon akarják rajtam behajtani, mert úgysem értem volna rá az egyéb feladatok között. És akkor '88-ra jött el az az időszak, hogy a Tőkei kutatócsoportjában kezdtem magam nem olyan jól érezni, ami valószínúleg igazságtalan, mert az egyik legjobb szellemi mühely volt Budapesten még akkor is. De mindenesetre, amikor kiderült, hogy a Hopp múzeum igazgatót keres, én akkor oda elkerültem. Nem jelentkeztem, hívtak, és még akkor is tünődtem egy darabig, de aztán azt gondoltam, hogy ebbe nekem bele kell vállalkozni, mert a kutatócsoportban nem lesz jobb már, és akkor, ha se ezt, se azt nem tudom csinálni, akkor annak nincs értelme. És akkor elmentem a múzeumba.

Úgyhogy tulajdonképpen ennyi lett, és hát ott aztán becsületesen be voltam havazva szintén, hát ugye az első két évben meg kellett tanulni, hogy mi az, hogy egy múzeum belülröl. Illetve azt már tudtam (azt is megmondom mindjárt, hogy miért), de azt, hogy ez a múzeum mit tud, és mit kell benne csinálni, hát azt is meg kellett tanulni. Abba belement körülbelül két év. Aztán utána már akkor inkább a rutinok szerint is lehetett csinálni, de azért sok feladat az. Sok feladat.

Úgyhogy a tangutoknak nem volt nagyobb szerencséje velem, de lehet, hogy nálam ifjabb kutatók jobban fogják csinálni. Én nem föladtam, hanem elcseréltem egy kicsit. Tulajdonképpen a dolgot én evidenciában tartottam, és meglehetösen sokáig naprakész is voltam, hogy mi jelenik meg, vagy mi jelent meg. Talán japánul nem, de egyébként igen. Tudván azt, hogy japán nélkül ez sincs, de az más lapra tartozik. Az, hogy tényleg kutatóként, beosztottként is meg még beosztottabbként is elhalmoztak annyi feladattal, hogy nem fért bele, csak apróságok. Amikor a múzeumba kerültem, akkor meg érthető, hogy miért nem fér bele, csak megint apróságok, illetve 
akkor meg úgy éreztem, hogy nekem a múzeumban kell publikálni vagy találni valamit.

Találtam is olyat, amit a múzeumban senki nem kutatott, és most már divattéma, a fene egye meg, mert hogy én nem tudtam a könyvemet megjelentetni korábban belöle, amikor még nem volt divattéma. Tudniillik az újévi képek, a tradicionális újévi képek. Most az a nagy helyzet, hogy végül is egy félév kéne úgy, hogy egyéb feladatokkal ne legyek megsorozva, és akkor talán még meg is lenne, mert nem sok híja van. Egy-két könyvet kellene elolvasni, még egyszer megnézni, hogy jelent-e meg a legutóbbi egy évben valami érdemleges, mert azt nem tudom, de odáig naprakész voltam a dologban. Az utolsó másfél évben meg nem volt a kezemben, ami nagyon rossz dolog, de hát a Barnabásnak segítettem. Hogy mondjam, ezek a női dolgok ugye, hogy az természetes, hogy én mint a felesége segítek neki, és senki más sincs hozzá olyan közel, hogy a fordításban segítsen, és reggel meg este meg alkalmanként, időnként öt percig, időnként órákon át ezzel foglalkozzék. Úgyhogy úgy tünik, hogy ez így van rendjén. Ez van.

Még annyit talán a tangutokhoz, hogy a tanszéken a '90-es években, egészen 2002-ig voltak speckoljaim (aztán még később is voltak, de abban már nem emlékszem rá, hogy ilyen lett volna), amik tulajdonképpen a tangutokról szóltak. Megintcsak ugye müvelődéstörténeti összefüggésben, egy egész féléves kurzus, kutatástörténet, ami szintén nagyon tanulságos, megfejtések története, nem kevésbé tanulságos, és aztán az, hogy most hogy állunk. Azt hiszem, hogy elég érdekesre sikeredtek. Több évig volt újra-újra, vagy néhány évenként újra elővettem, és hozzátettem, ami közben kiderült, újabb felfedezés vagy megfejtés. Úgyhogy ilyenek voltak. Még a kilencvenes évek elején is tettem egy eröfeszítést azért, hogy legyen egy PhD-disszertáció a tangutokból. Barnabás ugyan mondta, hogy nem tartja reálisnak, mert nincs mögöttem tízéves folyamatos kutatás, amiben igaza volt sajnos, csak mindig valamibe belekaptam valamennyire. De mondjuk én megtettem azt, amit az egyetemmel el kellett intézni ezen ügyekben, de aztán úgy jött az utolsó múzeumi felkérés kötetben való részvételre, erre-arra, hogy aztán lecsúsztam a disszertációnak az utolsó határidejéröl.

GI: De akkor a disszertáció meg van írva?

FM: Épp az, hogy nincs annyira megírva. Persze én is szamár vagyok, mert hát bizonyos igényeket el lehet engedni bizonyos esetekben. De nagyon 
nem akartam, úgyhogy ez a hajó elment. A múzeumban sok szép dolog készült, az utolsó munkám az a nagy könyvkiállítás volt, ami Pekingből jött, nem készen. Tehát itt készült a katalógusa, ó borzalom!

GI: Nem sikerült? Hogyhogy „ó borzalom”?

FM: Gyönyörüre sikerült. De azért ó borzalom, mert a derék kínaiaknak annyi gondot okozott az, hogy, atyaisten, ha már régi könyvekröl beszélünk, akkor legalább a könyvek címét tessék fantizivel írni. És így tovább. És aztán kiderült, hogy tulajdonképpen egy kattintás a számítógépen előhozza a fantiziket, csak itt jön a rákfenéje annak, hogy az egyszerüsítés következtében bizonyos írásjegyeknek megnő a szemantikai terhelése, és nem a megfelelőt hozta elő a régiből. Tehát végül is annyi lett a katalógus, amit én ezek nélkül az anyagok nélkül meg tudtam csinálni, ami egy abszolút korrekt katalógus. Egy-két hibával, az mindig kell, hogy legyen, anélkül nem megy. De az anyagnak egy nem kis része, amit a kínaiakból sikerült kiimádkozni, az nem lett leírva, mert hát nem volt itt használható formában akkor, amikor már le kellett zárni. Pedig most nem hosszú a nyomdai átfutás, de hát tényleg vártam az utolsó napokig.

GI: Tényleg, amikor voltam itt decemberben, utánaolvastam valahol, hogy pont volt egy másik kínai könyvkiállítás a Várban.

FM: Igen, az Taiwanból jött.

GI: És annak a Tanárnő nem volt része?

FM: Nem voltam része, és sajnos nem is láttam, amit fölöttébb sajnálok. Csak úgy tudok elmenni itthonról, hogy ha a Barnabással itt van valaki. Nagyon rendes családom van, de odáig nem jutottak, hogy ilyen kimenőket nekem szervezzenek és engedélyezzenek.

GI: Akartam kérdezni a nemzetközi kapcsolatokról is. Az akkori magyar sinológia, a '60-as, '70-es, '80-as, '90-es évek magyar sinológiája hogy kötődött kelet felé, nyugat felé, Kína felé?

FM: Elöször talán azt kell mondanom, hogy kétfelé kötődött. A Barnabás már beszélt a Fiatal Sinológusok Szövetségéröl $1{ }^{14}$ A háborút átélt, háborút túlélt európai sinológusok alkották ezt a szövetséget, és igyekeztek valamennyire kezet nyújtani a kelet-európaiaknak is. Ez időnként anyagi okokból is nehezen ment (mármint innen felöl), időnként meg - különösen '56 elött - politikai okokból is elég nehézkes história volt. Tehát nem volt sok kapcsolat '48-ig. Volt, aztán nem volt. Ezt ő jobban elmondta,

14 Lásd „Interjú Csongor Barnabással”, Távol-Keleti Tanulmányok 10:1 (2018), 22. 
mint amennyire én tudom. Ezt csak azért akarom emlegetni, mert hogy aztán 1960-ban Moszkvában volt az orientalista nagy világkongresszus, és hát ott voltak innen is, onnan is, amonnan is. Érdekes módon azzal lettek meg tulajdonképpen a magyar sinológiának mondjuk a szovjet kapcsolatai is, meg valamilyen módon megerősödtek a nyugati kapcsolatok is.

A Népköztársaság megalakulásától kezdve, még sokáig nagy gyéren voltak szakmai kapcsolatok. Könyvet lehetett rendelni, ha egyébként megtudtuk az adatokat. De nagyon gyéren voltak, mert még nagyon erősen munkált a kínaiakban az, hogy a sinológusok tekintélyes része az a gyarmatosítók ügynöke vagy embere, vagy valami ilyesmi. Tehát gyanakodva nézték, fogadták az embert. Én elkezdtem '62-tôl járni az Európai Sinológusok Konferenciáira. Amikor már dolgoztam, akkor össze lehetett spórolni egy utazásra a pénzt. Turistaútlevelet akkor még nem lehetett kapni minden évben nyugatra, de olyan volt, hogy az ember megkérvényezte, hogy ilyen konferenciára, ahol ezt lehet tanulni, ezt tudom előadni, és akkor szüken kimérték a valutát, amit ki kellett fizetni persze. De annyira szüken és úgy mérték ki, hogy azt mindig külön meg kellett írni és kérni a konferencia szervezöitől, hogy hát nem tudjuk előre kifizetni a részvételi díjat, csak majd a helyszínen, ha már sikerült odaérni.

Na most egyik érdekes benyomás volt az, hogy ezeken a konferenciákon fordultak elö huaqiaók vagy a Népköztársaságból jött emberek. Ök rendszerint a nyakába estek az embernek, ha kínaiul szólalt meg. Mert a nyugat-európai sinológusok között ez akkor ritka volt, mert ők meg nem tudtak menni akkor még a Népköztársaságba sem és Taiwanba sem. De aztán lassan ez a dolog úgy feloldódott, és akkor ahogy létrejöttek ezek a kulturális csereegyezmények, miegyebek, aztán a tudományos egyezmények, akkor lehetségessé váltak a különböző ilyen kisebb-nagyobb utazások, kapcsolattartások, miegyebek. Nekem kétszer jutott, az az előbbi, amit az előbb emlegettem, a két hónapos '85-ben, és két évvel később meg a háromhetes - de dunhuangi - kirándulás, ami szintén óriási jó dolog volt.

Nekem Taiwannal, taiwaniakkal nemigen volt kapcsolatom. Már múzeumigazgató koromban volt, hogy egyszer - azt hiszem saját kezdeményezésükre - fogadtunk egy állatövi jegyekröl és ezekhez kapcsolatos szokásokról, mindezt kortárs iparmüvészetben elővezetve, egy ilyen kiállítást. Akkor ezzel kapcsolatban voltak itt szakemberek. Mit tudok még erről mondani? Taiwanból volt itt kollega, mit tudom én, textilrestaurátor, ami azért volt nagyon érdekes, mert ott majdhogynem élő dologként vannak 
azok a régi textilek, szépségek, ami itt csak mint múzeumi tárgy képzelhető el. És hát meg akarta nézni, hogy nálunk hogy bánnak vele, és a mieink meg megnézték, hogy ö hogy bánik vele. Ezek olyan nagyon jó dolgok voltak. Aztán tartottuk a kapcsolatot. Ez a restaurátor hölgy, aki egyébként ott Taiwanban a Dunhuang-szakértők egyike is, azt hiszem a mostani utódommal, Fajcsák Györgyivel, aki most a múzeum igazgatója, azzal máig levelez.

Tulajdonképpen most már sokfelé vannak kapcsolatok. A Györgyi volt az első egyébként, aki egy évig volt ösztöndíjjal Kínában, aztán egy évig volt Londonban, ugyancsak egy ösztöndíjjal. Aztán megjárta Taiwant is most már azóta. Tehát innen is, onnan is szedte össze a tudomány különböző aspektusait. És minden ilyen látogatás kapcsolatokat alapoz meg, és azokat nagyjából tartják is. Én már kívül vagyok ezeken a mulatságokon.

GI: Például amikor a Tanárnő tanguttal foglalkozott, akkor az orosz tangutkutatókon kívül kiknek a műveit olvasta? A kínaiakét?

FM: A kínaiakét mindenképpen, aztán ismertem a Dunnell kisasszony ${ }^{15}$ műveit is. Körbenéztem, és láttam azt is, hogy vannak japánok is (a Nishidával ${ }^{16}$ találkoztam is), többen is, és Taiwanon is van egy-kettő, aki ilyennel foglalkozik.Várjon csak, az elsők egyike, aki komputerrel kísérelte meg valamire menni, az volt a Grinstead. ${ }^{17}$

GI: A British Múzeumból. Először ott volt, aztán utána átment Dániába.

FM: Igen, én már úgy tarottam számon, mint dániai. Vannak szövegtöredékek Stockholmban is, meg itt, meg ott, nem tudom pontosan, hogy hogy kerültek oda, de azokat már a Kszényiját ${ }^{18}$ hívták meg feldolgozni vagy megnézegetni közelebbröl.

GI: Zárógondolatként vagy témaként azt kérdezném meg, hogy a modern Kínát hogy látja a Tanárnő? Akár kutatás szempontjából, akár bármilyen szempontból. Miként szembesül vele?

FM: Annak idején, ha megkérdezték tőlem, hogy milyen Kína, azzal szoktam kezdeni a partner bosszantását, hogy Kína nem ország, hanem egy világ-

15 Ruth Dunnell, amerikai történész, jelenleg a Kenyon College professzora. A tangutológia egyik legjelentősebb angol nyelvű müvelöje.

16 Nishida Tatsuo (1928-2012), japán nyelvész, az 1960-as évektől kezdve az egyik legnagyobb hatású tangutkutató.

17 Eric D. Grinstead (1921-2008), új-zélandi sinológus, aki a British Múzeum kínai kéziratainak és nyomtatványainak kurátoraként először kezdett el Stein Aurél tangut gyüjteményével kapcsolatban publikálni.

18 Kszenyija Boriszovna Kepping, lásd 7-es lábjegyzet. 
rész. Tehát annyiféle mindenféle van benne, és van egy csomó minden, ami egységes. Na most amikor én szembekerültem ezzel a világrésszel és egy másik civilizációval, ami Kína volt, akkor a rácsodálkozás után az következett, hogy lassan megtanultam azt, hogy mi fáj a kínaiaknak. Tehát, hogy egy csomó olyan dolog, amire én azt hittem, hogy istenem, én tanultam történelemből, hogy azon más is túllépett, azon nem is olyan egyszerü túllépni. Tehát a kínaiaknak is még sok minden fájt, és most azt kezdem látni, abból a kevésből is, ami hozzám eljut, és amit látok és észreveszek, hogy egy része már náluk is megtalálta a helyét ezeknek a dolgoknak a történelemben. És ez nagyon jó.

Hogy mi van még hátra, vagy milyen tennivaló van még ez ügyben, azt én nem sorolnám föl, mert nem vagyok vele tisztában, hogy mennyire kevéssé látom át a mai viszonyokat. Illetve tisztában vagyok vele, hogy nem láthatom át egészen a mai viszonyokat. De az biztos, hogy nagyon más most, mint régen. Hogy egy témánkba vágó példát mondjak, ami egy nagyon-nagyon pici részlet és nem a nagy szembesülés dolga, az például az, hogy én még azt tanultam (és tapasztaltam is, mert volt olyan ismerős, akinél ezt lehetett tapasztalni), hogy a kínai fogalmak szerint barbár ősökre (nem tangutokra éppen, hanem ebben az esetben a mongolokra) nem voltak büszkék. A nagy kínai kultúrájukra nagyon. De a mongol ősöket titkolták, mint valami bünét a régvolt ősöknek. Néhány évvel ezelőtt, tehát már az új időben, az új évszázadban, már hallottam az illetőt, amikor leszögezte, hogy az ő ősei egy külön színt képviselnek vagy képviseltek a kínai kultúrában, merthogy mongolok voltak. Ez énszerintem akkora változás és olyan jelentős, hogy nehéz eléggé méltatni. No hát, valahogy így.

GI: Rendben. Akkor köszönöm szépen az interjút.

FM: Ha segíthettem, nagyon szívesen. 